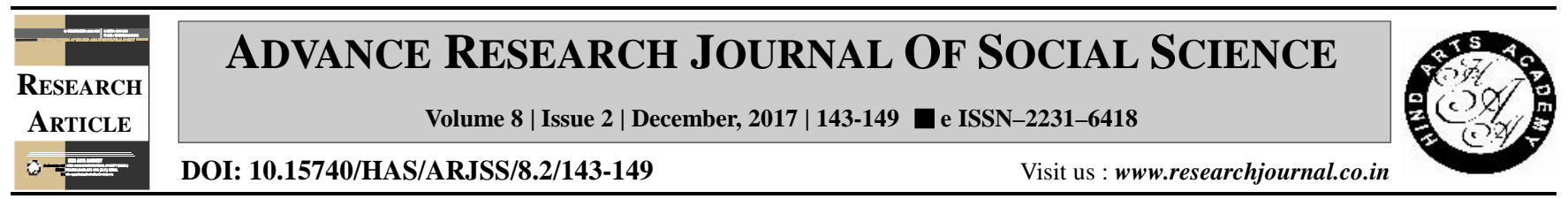

\title{
Incidences of cyberbullying among adolescents
}

Himakshi Baruah, Pragaya Dashora* and M.K. Chaudhary ${ }^{1}$

Department of Human Development and Family Studies, ASPEE College of Home Science and Nutrition, Sardarkrushinagar Dantiwada Agricultural University, SARDARKRUSHINAGAR (GUJARAT) INDIA

${ }^{1}$ Department of Foods Science and Nutrition, ASPEE College of Home Science and Nutrition, Sardarkrushinagar Dantiwada Agricultural University, SARDARKRUSHINAGAR (GUJARAT) INDIA

(Email: himakshibaruah23@gmail.com, pragayadashora@ rediffmail.com)

\section{ARTICLE INFO :}

$\begin{array}{lll}\text { Received } & : & 26.05 .2017 \\ \text { Revised } & : & 15.09 .2017 \\ \text { Accepted } & : & 01.10 .2017\end{array}$

\section{KEY WORDS :}

Cyberbullying, Adolescents, Nature, Environment, Extent

HOW TO CITE THIS ARTICLE : Baruah, Himakshi, Dashora, Pragaya and Chaudhary, M.K. (2017). Incidences of cyberbullying among adolescents. $A d v$. Res. J. Soc. Sci., 8 (2) : 143-149, DOI: 10.15740/HAS/ARJSS/8.2/143-149.

*Author for correspondence

\section{ABSTRACT}

India stands third in the globally visible serious issue of cyberbullying. Urban adolescents are enormous user of technology and Ahmedabad being one of the top city of Internet users is supposed to be at high risk. The study was aimed to examine the nature and extent of cyberbullying among adolescents of Ahmedabad city of Gujarat state. The sample consisted of 240 respondents ( 120 boys and 120 girls) from standard VII to XII of two private co-educational English medium schools. Self - prepared questionnaire and modified version of Cyberbullying and Online Aggression Survey Instrument (Hinduja and Patchin, 2015) was used to elicit the data. Involvement in cyberbullying was seen for life time and for last thirty days before gathering the data. Findings indicates that nearly fifteen (14.17\%) per cent respondents were involved in cyberbullying in their lifetime whereas seven $(6.67 \%)$ per cent were involved in last thirty days. The most common ways of cyberbullying were posting mean or hurtful comments and spreading of rumours. Computer instant messages and Facebook was most usual online environment where cyberbullying occurred. Overall, the extent of involvement of respondents in cyberbullying was low but it was sufficient enough to identify its emergence in our society. 